CREATING MARKET SOCIALISM 


\section{POLITICS, HISTORY, AND CULTURE}

A series from the International Institute at the University of Michigan

Series Editors: George Steinmetz and Julia Adams

Series Editorial Advisory Board: Fernando Coronil, Mamadou Diouf, Michael Dutton, Geoff Eley, Fatma Müge Göcek, Nancy Rose Hunt, Andreas Kalyvas, Webb Keane, David Laitin, Lydia Liu, Julie Skurski, Margaret Somers, Ann Laura Stoler, Katherine Verdery, Elizabeth Wingrove

Sponsored by the International Institute at the University of Michigan and published by Duke University Press, this series is centered around cultural and historical studies of power, politics, and the state - a field that cuts across the disciplines of history, sociology, anthropology, political science, and cultural studies. The focus on the relationship between state and culture refers both to a methodological approach - the study of politics and the state using culturalist methods - and to a substantive approach that treats signifying practices as an essential dimension of politics. The dialectic of politics, culture, and history figures prominently in a 11 the books selected for the series. 


\section{CREATING MARKET SOCIALISM}

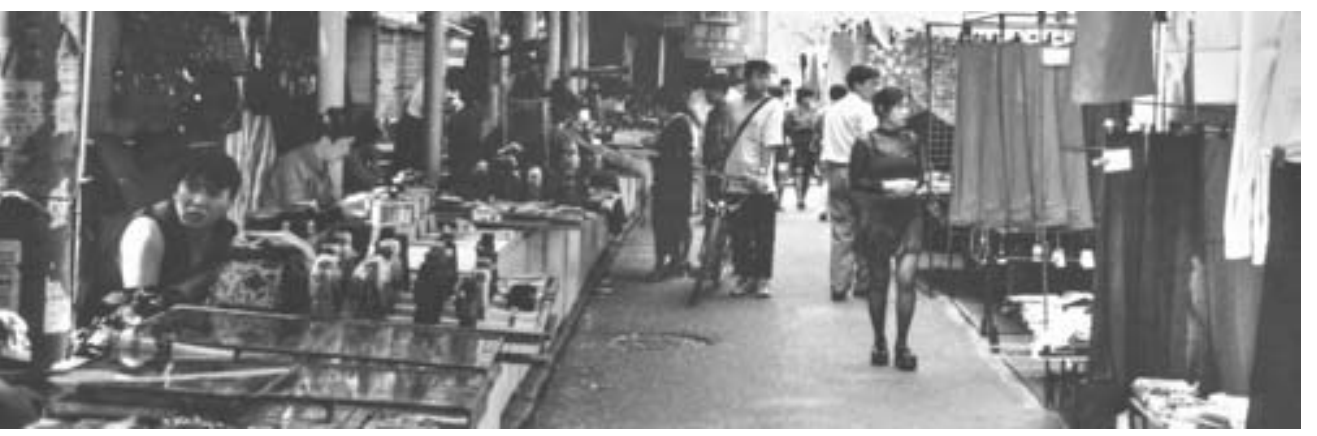

How Ordinary People

Are Shaping Class and

Status in China

\section{Carolyn L. Hsu}

Duke University Press Durham and London 2007 
(C) 2007 Duke University Press

All rights reserved

Printed in the United States of America on acid-free paper @ Designed by Heather Hensley

Typeset in Garamond Pro by Tseng Information Systems, Inc.

Library of Congress Cataloging-in-Publication Data appear on the last printed page of this book.

Duke University Press gratefully acknowledges the support of Colgate University Research Council, which provided funds toward the production of this book. 
To my friends in Harbin 
